\title{
Review Article.
}

\section{FIRST CHEMIST OF THE WORLD**}

\section{Introduction}

The Arabs entered the land of ancient civilization, the near East in the middle of the 7 th century with a dynamic and a virile religion and a language of Divine sanction. This rich and llexible tongue soon became the only scientific language of the period. This supremacy of Arabic contintied uninterrupted throughout the then scientilic world up to the European Renaissance. when the Latin grew into a medium of scientific understanding in the West.

By the time the Byzantine and Persian Empires were.conquered by the Muslims. Greek science had almost ceased to exist. There is no improvement to the Greek science by the Romans and Byzantines, who had no interest in scientific discourses. Only a few Scholars mostly the Jews and the Christians who in isolated solitudes continued the study of the great works of Aristotle (400 B.C). Hippocrates (500 B.C). Galen (200 A.C)." Ptolemy and Archimedes. Among the few post Greek and pre-Islamic scholars the following are worth mentioning:-

Aetios of Amida (550 A.C)., Paul of Aegina (625). Alexander of Tralles (525-605) domiciled in Rome and Theophilos Protospatharios of Constantinople (640).

So for about four centuries the world had no scientific activity in a large scale. except the isolated works of the above few in the Roman Empire. Persia. India and China. In the 7th century, the Muslim came into the forefront.

In this period of intcllectual stagnation some feeble scientific activity was evident in Egypt.

Egypt was the oldest civilization known in history. The Egyptian Period extended from 5000 B. C. to 500 A.C. But there was no significant activity in the early Christian era. During this time the medical learning was started on a new basis with the teaching of Galen.

Soon the famous Johannes Philoponus of Alexandria became the advocate of the Philosopy of Aristotle and the Alexandrian workers condemned the workers of Hippocrates. All these were due to Christians fanaticism and mysticism, which was not a favourable soil for any scientific development. It is for this reason, inspite of some scholastic activity. Egypt totally failed to act as an intermediary between Greek and Arabic medicine and science (Meyerhof 1952). The fanatically religious Christians of Egypt did not allow independent scientific activity. The Greek science was revived by the Arabs from the Syriac speaking world. The neo-Aramaic or Syriac-words gradually replaced the Greek in the Near-East from 3rd century onwords. The main scholars of this Syro-Hellenistic

\footnotetext{
* A.C means After Christ in contrast to B.C. which meams Before ChrisL. It is belter than A.D. which means After Death. as the Death of Christ is controversial.

* From Muazcam, M.G, E.P.M.J. S (4) : 1-6, 1961
} 
civilization were the Nestorian Christians. But this sect was established only in 428 A. C. by the patriarch of Constantinople-Nestorious. They were condemned as heretics by the council of Ephesus in 431 and they migrated to Edessa. The Byzantine emperor Zeno expelled them from Edessa in 489 and they migrated to Persia during the Sasanian rule. The Nestorlans brought with them the Greek works from Edessa first to Nisibis of Mesopotamia. From there in the 6th century they transferred their medical school to Jundishapur of Sasanid Persia. The Greek scholars migrated to Sasanian persia when the Justinian closed the Philosophical school of Athens in 529. Before this in 4th century the Sasanian Monarchs established a large hospital and scientific academy. The mightly Persian king Chosroes Nushirwan (531-579) took the help of the migrated Greek scholars and made Jundishapur the most important intellectual centre of the then world. Where the Scholars of Greek, Persia, Syria. India and China could meet and exchange their isolated knowledge and gave rise to a scientific Synchronism. This vast treasure and a close follower of scientific wealth formed the basis of the development of Islamic thought. Chosroes sent his personal physician to India in search of medical books. These Sanskrit books were translated into Pahlavi (old Persian) and later on all the scientific books were rendered into Syriac. One of the Scholars of Jundishapur Hazrat Sulman Farsi was a contemporary of Holy Prophet and lived in Medina during the rise of Islam. He was the first scientifically trained Medical man of Arabia and did help the Prophet on several occasions by his scientific knowledge. It is from him that the Prophet took the idea of making a ditch around the city of Medina as a precuationary measure against the infidels of Mecca during the Battle of 'Ditch' (Khandak).

After several centuries of intellectual bankruptcy and darkness a bright light apeared in Arabia with Divine misson. He was the Holy and the last prophet of Allah- Hazrat Mohammad (peace be on him). With his teaching and ideal, within few years of his death, his followers became the most formidable force in the then world. The Romans. Byzantines and the Persians all disappeared from the Middle East. After the establishment of a vast Islamic state, the Muslims came in touch with the vast store house of Greek scientific knowledge. The Arabs inherited a religion suitable for the best way of life and they were ardent seekers of truth.

When the Arabs overran north Africa and western Asla, they left Byzantine and Persian administrative and scientific institutions almost untouched. The academy of Jundishapur became the scientific centre of new Islamic Empire. During the Umayyad period (661-749) Damascus, the capital, became the centre of learning mainly for medicine. At this time a Persian Jew Masarjawaih translated a preIslamic medical treaties- Pandects of Ahron- into Arabic. This is regarded as the earliest Arabic translation of a scientific book.

Then during the Abbasids period the real Islamic contribution started in the scientific lield.

The accompanying figure will show the tributaries of scientific knowledge which joined togather to form the starting point of the vast Sea of Islamic science which is still flowing as a part and percel of the modern ocean of sclentific store house. 
The first thing the Arabs did was that, they began to translate scientific works into their own language. This continued upto the 9th century. The Arabs did not remain simply the followers of Greek knowledge, some of them also started independent thinking. The most illustrious among them was Jabir Ibn Hayyan whose "shadow lies athwart the science of the Middle Ages in the Orient as in the Occident." He was the father of Al-chemy which has given birth to modern chemistry. Jabir Ibn Hayyan (720-812 A.C.) was called 'as-Sufi' in the Middle Ages and Geber in the Medieval Latin literature. He was the son of an Arab druggist of Kufa. He was closely associated with the viziers of powerful Harun-ar-Rashid (809 A. C) the Abbasid Caliph. (Meyerhof 1952).

There is some obscurity about the activity and life of Jabir. It is of interest to note that his alchemical and Medical writings, though contain works of the Greek and Persians but there is no mention of Mesopotemian and Indian drugs and poisons. So, it is evident that he was living in the early era of Muslim period.

From the translation of the Hellenic works the Arabs took the belief that the base metals can be transformed into gold. Even in the 7th century A.C Khalid Ibn Zeyad-an Arab Muslim, was writing on the subject. Such idea was also prevalent in medieval India and people believed the existance of a stone (Ëkrv $\mathrm{kJgr}$ ' or touch stone) which on touch could transform any ordinary metal to gold. "This early theories found their fullest expression in the experiments and writings of the famous alchemist known as Geber whose real name appears to have been Abu Musa Jabir Ibn Hayyan" (Khan 1957).

He is said to have been born at Tus, near the Persian city of Meshed. He went to Hinyari in Arabia for studies, from where he went to Bagdad and soon became the friend of the Prime Minister of Harun-ar-Rashid. In his retired life he went to Kufa where he spent most of his time in research and about two hundred years later his laboratory was discovered near the Damascus gate of the city. Jabir is world famed as the Father of Alchemy or the First Chemist of the World. The word Al-Kimiya (given by the Arabs) is said to have been derived from the Egyptian Kam-it or kem-it (the black) or the Greek world Chyma (molten metal). Though this alchemy first of all remained in the hands of theoretical philosophers, it is Jabir who brought it in the realm of science and experimental research.

About 100 books which have been compiled by Jabir still exist. Many of his works prove that the author recognised more clearly, and stated more definitely the importance of experiment than any other early chemist. Thus he made noteworthy advances in both the theory and practice of the subject. His influence can be traced throughout the whole historic course of European alchemy and chemistry (Meyerhof 1952).

He improved many practical methods of chemical analysis and had written details of the methods of evaporation, sublimation, filtration, distillation, melting and crystallization etc. He described the methods of obtaining almost pure vitriols, alkalis, alums, sulphide of mercury (cinnabar), arsenius oxide, salt peter,saltammoniac, mercury oxide, acetates of lead and other metals. He was the first to 
prepare crude Sulphuric, and Nitric acid and their mixture-Aqua regia. He also knew that Gold and Silver can be dissolved in this mixture. He is said to have discovered the spirits of wine and elixirs. In his writings be has narrated how he saved the life of a slave girl of Yahya bin Khalid-Barmaki by elixdr (Aziz 1959).

Out of his 100 books only a few smaller ones have so far been translated into modern languages. Nine of his theses translated by $\mathrm{O}$. Houdas are available in "La chemic au Moyen Age" of M. P. E Berthelot. The most important books of Jabir on alchemy are: Book of the kingdom, Little Book of the Balances, Book of concentration, Book of Eastern Mercury etc. He evolved a theory of geological formation of metals-Sulphur mercury theory and discribed six principal metals based on the different proportions of sulpher and mercury in them.

Jabir also described the method of preperation of basic lead carbonate, arsenic and antimony from their Sulphides. According to Sarton, Jabir also described the "Refinement of metal, preperation of steel, dyeing of cloth and leather, varnishes to water-proof cloth and to protect iron, use of manganese dioxide to colour glass, iron pyrites for writing in gold and distillation of vinegar to concentrated acetic acid. (Khan 1957).

Though Jabir failed to transform metals into gold, he started experiments and enunciated theories which lead to discovery of a large number of equipments and chemicals which formed the basis of modern chemistry.

Several technical terms has paassed from Jabir's Arabic writings to European launguages, some of these are: realger (red Sulphide of arsenic), tutia (Coppersulphate), alkali, antimony (Arabic : Ithmid), alembic (upper part of the distallation vessel), aludel (lower part of the distallation vessel), Sal ammonic etc. "A full appreciation of Jabir's merits in chemistry will only be possible when bulk of his chemical wrtings have been published particularly his great Book of the seventy. This composition of seventy discourses was till recently availabie only in an incomplete Latin version.

His chemical books were translated into Latin very early, the first being the Book of the composition of Alchemy which was rendered into Latin by Robert of Chester,an English,in 1144 A.C. The incomplete Latin version of the Book of seventy was made by the famous Gerard of Cremona (died 1187). Another English translator Richards Russel rendered one of the Jabir's books into English under the title of 'Sun of perfection'only three centuries before in 1678. Russel discribed him as 'Geber' the most famous Arabian Prince and Philosopher.' Dr. E.J. Holmyerd have brought out many convincing evidences in support of the idea that, Latin 'Geber' is the father of Alchemy, Jabir ibn Hayyan.

Jabir was an important figure in the court of the Abbasids due to his attachment with the Barmecides. The family of the Barmecides met their downfall in 803 A.C. to which Jabir was implicated. He then left Bagdad,went to his father's place at Kufa, where after doing extensive research work he died in exile.

\section{Acknowledgement}

I think Lt. Col M.M. Haque for his kind permission to published the paper and the Dr. P. Ispahani for the diagram. 


\section{References}

Aziz, A. Chemical knowledge- of the Greeks and Arabs(1959) Hamdard Medical Digest, Karachi, January Issue, P. 4.

Khan R.M. The first Chemist (1957), Hamdard Medical Digest, November issue P. 3-5.

Max Meyrhof (1952) Lagacy of Islam, London P. 312.

Muazzam M.G. (1959) A choronological history of the discovery of the circulation of Blood and contribution of ibn Nafis, East Pak. Med. Jour. Dacca, Vol III No. 3. P. 1.

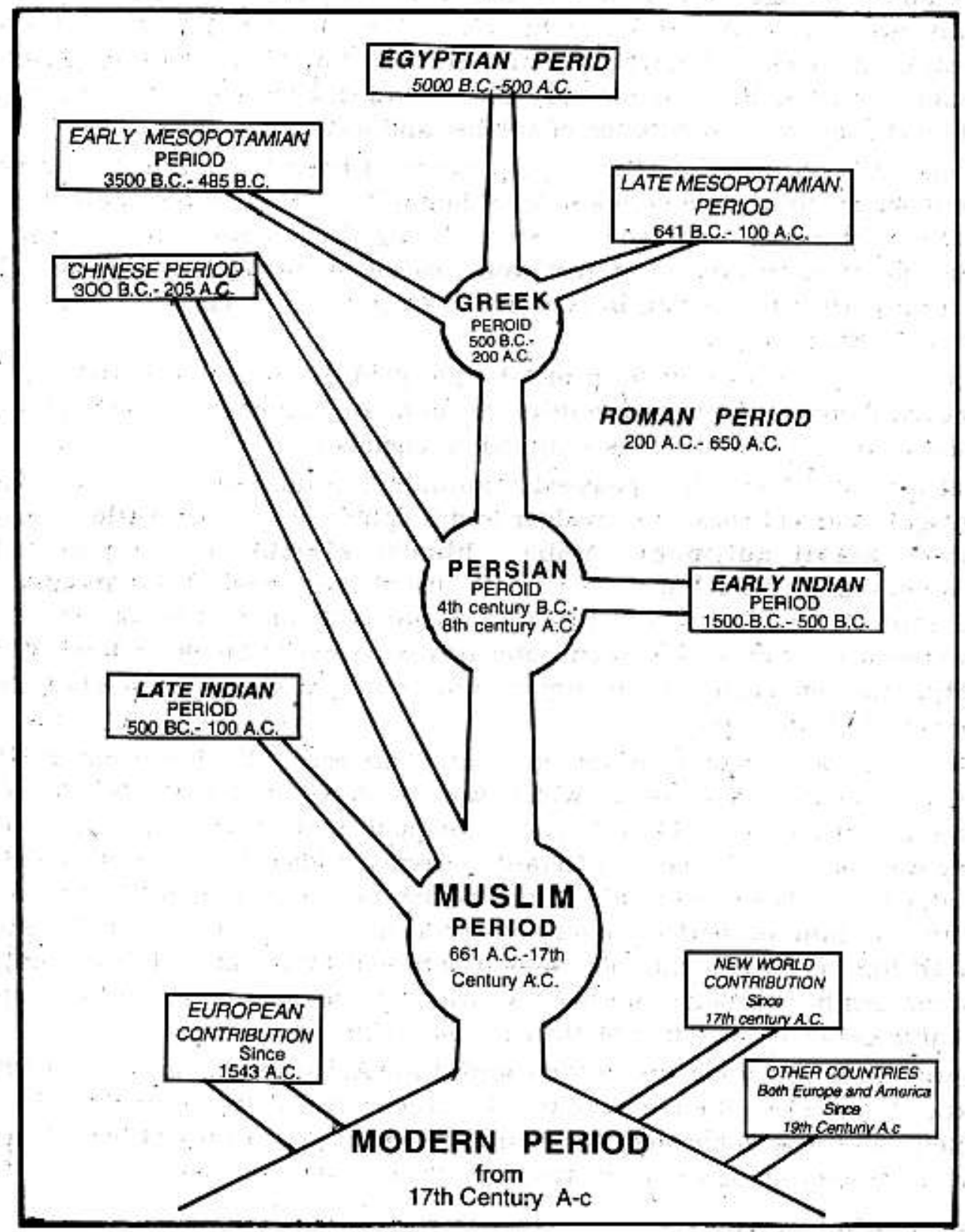

Fig. 1. A diagramic represation of the gradual development of modern science from the prehistoric period to the 20th century of the Chirstan era (Copiled from Muazzam M.G. 1959). 